\title{
Reflections on the Subjects of Rural Collective Land Ownership
}

\author{
Fu-Jiang SUN ${ }^{1, a}$, Jing-Ling $\mathrm{SHU}^{2, \mathrm{~b}^{*}}$ \\ ${ }^{1}$ Department of Public Management, University of International Relations, Beijing (100091), China \\ ${ }^{2}$ Department of Legal Affairs, China University of Political science and Law, Beijing (100091), China \\ asfj.006@163.com, ${ }^{b} 931932720 @ q q . c o m$ \\ * Jingling Shu
}

Keywords: rural collective land ownership, collective, subject, ownership by a community, land share-holding cooperative

\begin{abstract}
The paper believes that ambiguity of the subjects creates the fundamental drawback in China's regime of rural collective land ownership. To redevelop rural collective land ownership, its nature and subjects should be clearly defined, and land share-holding cooperative should be set up as the agency and operating mechanism for exercising rural collective land ownership, according to the theory on ownership by a community in civil law. It would be a feasible option to realize the principal status of rural collective land ownership and effectively improve land ownership regime.
\end{abstract}

\section{Introduction}

The regime of rural collective land ownership serves as a way to realize China's public land ownership system, and is the fundamental regime among China's rural land system, on the basis of which the regimes with rural land as the object are established. Currently, a variety of problems arising during the implementation of rural land regimes, such as illegal expropriation of rural land, random alteration or deprivation of land contract management right and etc., are closely relevant with collective land ownership, though they appear to be caused by nonobservance with laws and regulations. The paper holds that paying due regard to ambiguity of the subjects in rural collective land ownership regime and making improvements should be a practical method to efficiently address this issue.

\section{Ambiguity of the Subjects in Rural Collective Land Ownership}

It is generally acknowledged that China's collective land ownership, formed in the collectivization movement in 1950s, was featured by ownership to the three tiers (commune, production brigade and production team) and the production team serving as the basis, which was identified in the legislation in 1980s. With respect to the objects of rural collective land ownership, the Constitution provides: land in the rural and suburban areas is owned by collectives except for those portions which belong to the State as prescribed by law; house sites and privately farmed plots of cropland and hilly land are also owned by collectives. As regards to the subjects of collective land ownership, according to the Land Administration Law of the People's Republic of China, land owned by peasant collectives that belongs lawfully to peasant collectives of a village shall be operated and managed by collective economic organizations of the village or by villagers' committees; land already owned by different peasant collectives that belong to two or more different collective economic organizations in the village shall be operated and managed by the rural collective economic organizations in the village or by villagers' groups; land already owned by a peasant collective of a township (town) shall be operated and managed by the rural collective economic organization of the township (town).

Accordingly, the subjects of rural land ownership according to the laws should be the farmers' collective, more specifically, including three tiers: villagers team, villagers' committee, and villager collective at township. The rural collective economic organizations, villagers' team, villagers' committee, and the government at township are not the subjects of the ownership, because they are 
only entitled to operation and management, instead of ownership. Therefore, they enjoy the rights to operate and manage, instead of ownership. Their relationship with rural collective can only be understood as legal agency.

Hence, Chinese laws have made very clear provisions on the subjects of rural land ownership. But why do we still believe that ambiguity of the subjects creates the fundamental drawback in China's regime of rural land ownership? The paper holds that there are mainly two reasons:

\section{Firstly, the Connotations and Extensions of “Farmers' Collective” are not Clear-Cut enough, so Its Nature in Civil Law is Hard to Define.}

We may wonder whether the concept of "rural collective" refers to an organizational entity for farmers or their collective entity. According to the principles of civil law, ownership in nature should be categorized into property rights in private law. The subjects of the right only include natural person, legal person or unincorporated organization. The farmers' collective is obviously neither natural person, nor legal person or unincorporated organization. The concept of "collective" has found no corresponding carrier in practice. Therefore, it's hard to identify specifically what kind of subject the farmers' collective is.

\section{Secondly, the Farmers' Collective has no Independent Mechanism for the Formation and Expression of its Meaning. Its Status as a Subject Has Actually been "Blurred" and "Substituted".}

The connotations and extensions of this concept, and its legal attribute are hard to define, which leads to the difficulty in comprehending the nature of rural land ownership. Firstly, the farmers' collective and rural collective economic organizations are the subjects of ownership, while villagers' team, villagers' committee and the government at township are merely "legal agencies". These two groups of concepts carry different meanings. Secondly, the farmers' collective, no matter identified as a kind of organizational entity, collective entity or others, is a "group" made up by many individuals, and hence differs from natural persons.

As the farmers' collective is a "group", it should have a mechanism for the formation and expression of its meaning, different from the individuals. The question is that there are no explicit provisions in Chinese laws on the organizational form and procedures for the farmers' collective to exercise and realize ownership. So the will of the farmers' collective as a group in fact cannot be formed or expressed through some type of effective mechanism. The absence of the will of the principal (genuine subject of the right), i.e. the blurring of the subject, has led to the outcome that the will and actions of the agents, namely villagers' team, villagers' committee and the government at township, are probably not constrained by the will of the principal. In this way, "the agents" substitute the "principal” and naturally become the actual subject of the right. In reality, because the rural collective economic organizations have disintegrated or existed in name only, those that take over the status of the subject from the farmers' collective are mainly the administrative organs such as the government at township or villagers' committee. In some regions, ownership by the farmers' collective has turned to be ownership by a community of village officials or even by village officials individually.

The regime of rural land ownership has been created with an aim to protect the farmers' rights and interests over land. However, this regime has overall went futile, because the critical defect in its major structure, namely, the subjects of the right are unable to dispose the possessions and exercise the ownership at their own discretion within the scope provided by the laws. In this sense, the paper considers that ambiguity of the subjects poses the fundamental drawback in China's regime of rural collective land ownership. The fundamental drawback has caused the wide existence of willful encroachment on the farmers' rights and interests over land. For example, the government, even some officials, illegal appropriate the rural land and arbitrarily prejudice the farmers' right over land contract management. Confronted with these harmful behaviors, the farmers are incompetent to realize and protect the rights and interests of the owners by some effective legal mechanism. Therefore, it is uncommon for them to make a struggle through petitioning or even violent acts. 
In conclusion, it is imperative to make clear the subjects of rural land ownership and improve the regime for such ownership.

\section{Analysis and Comment on the Ways to Improve Rural Land Collective Ownership}

Since mid-80s in last century, the academia has mainly proposed four ways to improve the rural collective land ownership: (1) abolish the collective ownership and make the rural land state-owned [1]; (2) abolish the collective ownership and make the rural land privately-owned [2]; (3) adopt a diversified ownership; (4) adhere to collective land ownership, improve and develop a collective land ownership in real sense. The first, second and third ways are more influential. Their bases, feasibility and results are analyzed as follows:

\section{The Way to Make the Rural Land State-Owned}

This way means that the State has the ownership of the land owned by the rural collective and then transfers the right of its use to the farmers. This proposal has paid due regard to the reality of the collective land ownership controlled by the powerful and influential class of the rural areas and hopes to confine such rent-seeking by way of introducing in higher authority. The farmers are granted with the emphyteusis while the State the ownership, so as to ensure the farmers' long-term and stable rights over the land. But its feasibility calls for further discussions.

This approach would acquire or deprive without charge the land collectively owned by the farmers. With respect to acquiring the land, the Chinese government is incapable to afford such a huge amount of money. And if the government deprives without charge the land, which serves as the basis for the farmers' living and for the social guarantee, it would severely detriment the legal vested interests of the rural collective and the farmers and also the economic, political and social stability of our country.

In addition, the proposal would fail to efficiently overcome the drawbacks: ambiguity of the subjects of the rural land ownership and their substitution by "the agents". That's because the State, who is far away from the rural land and the large number of scattered farmers, would only have to rely on the established hierarchal agent regime (i.e. the governments at different levels and the original collective organizations) for land management, to realize its will as the land owner. This means path dependence and "old wine in a new bottle", which would not produce better results and would even fail to guarantee the farmers' rights and interests.

\section{The Way to Make the Rural land Privately-Owned}

This approach indicates that all the rural lands are distributed to the farmers individually, with a blameless purpose to ensure their most full and solid rights over the lands. However, it would give rise to the following problems:

Land privatization is inconsistent with the basic system of socialist public ownership, which is seriously risky politically.

Rural land privatization would inevitably result in land annexation. It would be hard to limit the number of land owned by individuals. The land's function as the social guarantee for rural population would be impaired by the farmers' loss of the land, which would compel these farmers into cities or towns with limited acceptance capacity and bring about a series of serious social problems in housing, employment, public security and etc.

If the rural land is privatized, the farmers would utilize the land, under the principle of individual utility maximization, for the industry, commerce, real estate and etc., to win higher proceeds. The arable land would be put into non-agricultural use and idleness and low-efficient use of such land cannot be avoided either. Moreover, the farmers would not choose to produce or provide farmland irrigation and water conservancy infrastructure, a "public product" that serves for the community non-exclusively. Consequently, it would be difficult for China to take a stride from the traditional agriculture to a modern one, and thereby have repercussions on China’s food safety [3]. 


\section{The Way to Adopt a Diversified Ownership}

This approach advocates that some parts of the rural land are owned by the State while some parts by the collective and others privately owned. It aims to reconcile the interests' relationships among the State, the collective and the individuals. We would have to face the following issues: 1) how to distribute the rural land among the State, the rural collective and the farmers; 2) how to harmonize their conflicts of interests; 3) the problems that would also arise from the above-mentioned ways.

In China, the rural land collective ownership is both a history and a reality, and will continue to exist for a very long term. Therefore, we should make improvements on the basis of retaining the regime of rural land collective ownership. It is crucial to make clear the subjects of the rural land ownership and the mechanism for realizing such right, so that the definite subjects are entitled to fully dispose the specific objects. We should recover the original significance of rural land collective ownership as a civil right, enable the rural land to break away from the control by village administrative organs and make it the property truly owned by the farmers.

\section{The Nature and the Subject of Rural Collective Land Ownership, and the Subject to Exercise the Ownership}

The rural land ownership should be developed after its nature is made clear. Currently, Chinese scholars have varied understandings on the nature of rural land ownership.

Firstly, some hold that the view that working class collective organization is the owner of collective land does not comply with the explicit provision of the laws such as Land Administration Law.

Secondly, some believe that collective land should be owned by the legal person of the collective organization and that members of the organization enjoy equity or membership right over collective property, which is mainly identified in the articles of association with more randomness [4]. There are on provisions on equity or membership right for cooperatives in Chinese laws.

Thirdly, some consider that China's land collective ownership is a new-type ownership by a community. Ownership by a community refers to a group of members with unfixed qualifications, who enjoy the rights in the name of the whole group. Its basic features are: the statuses of the members are relatively definite but not fixed; they are naturally entitled to relevant rights because of the status as a member, and naturally fail to enjoy the rights because the loss of the member status [5]. According to this doctrine, the members are granted the rights to possess, use and earn proceeds from the collective land, and exercise the ownership over the land in accordance with the principles of equality and voluntariness and the laws [6]. This paper believe that this doctrine is more compliant with China's reality and civil law principles over rural land ownership and could be adopted to make improvements on such ownership.

According to the theory, China's rural land ownership is enjoyed by all the members of the rural collective - the farmers' in the name of the collective and the farmers are the real subjects of the rights. The wills of the owners are manifested by the community and the ownership is exercised in the name of the community. Therefore the key to make clear the subject of rural land ownership is to coordinate the rights and obligations between the community and its members, so that the wills and actions displayed in the name of the community could truly reflect the wills and interests of its members.

To harmonize the wills of the community with the wills and interests of its members, the paper considers the following aspects are crucial:

Firstly, it should be made clear that the farmers are the owners of the land and the village administrative organs are neither the subject of rural land ownership nor have the right to exercise the right. The laws should neither provide that the entity to exercise the ownership must be village administrative organization, nor that any other form of "collective economic organization" be established to exercise the land ownership on the behalf of farmers. There should not be legal provisions on the mechanism to exercise the rural land ownership. The farmers, as members of their 
community, should have their own discretion to decide over the ways or the entity to exercise the ownership. Only by adhering to the principle of self-governance by the villagers can the rights be delegated to the people and the State's respect of the farmers' rights and free can also be manifested.

Secondly, the farmers' membership right should also be clearly identified and on this basis, the mechanism to form and express the wills of all the rights holders in the community should be built up. In view of the reality of China's rural economy and the administration by the government, a permanent representative body for rural land ownership will be beneficial to safeguard the interests of the members and promote the efficiency of property right and administration. Seen from the current practices in rural areas, the paper considers it practical and feasible for land share-holding cooperative to serve as the representative body for rural collective land ownership. The institutional set-up and the mechanism for the wills expression can be briefly introduced as follows:

All the members of the rural collective are members of the land share-holding cooperative and enjoy equal rights over the affairs with respect to the land. The cooperative adopts democratic management and the voting mechanism of one person one vote \& majority approval.

All the members of the rural collective are entitled to vote for the administrative organ and person-in-charge in a democratic way and according to the articles of association. The voting should be made on the basis of democracy, equality and consultation instead of other means, especially the intervention by the superior competent department.

In principle, the land share-holding cooperative, which is merely the representative body of the rural collective land ownership, deals with the renting, transfer, contracting and proceeds distribution of the land and should not get engaged in general operating activities.

All the members of the rural collective are entitled to obtain jus in re aliena according to law, such as homestead right, land contract management right, and also the proceeds from the collective property according to laws or articles of association.

In case of any damage of the property such as the collective land, the farmers have the right to select their representative to lodge a complaint to the Court and seek for legal protection.

\section{Conclusion}

We should make clear the farmers as the subjects of rural collective land ownership, and effectively form and express their wills through rural land share-holding cooperatives(as the representative body of the ownership and with the status of legal person). Only by doing this can we fully address the ambiguity of the subjects of rural land ownership and make the lands owned by rural collective truly at the hand of the farmers.

\section{References}

[1] Wang Liming (Chief Editor), Special Studies on Property Law, Jilin People’s Press, 2002.

[2] Wang Kejing, Research on China’s Rural Property Rights System, Shanxi Economic Press, 1993, pp.372.

[3] Pu Fanghe, Study on the Rights over Rural Land in China [master degree paper], Hunan Province, China, Xiangtan University, 2004, pp.5-7.

[4] Kong Xiangjun, Research on New Issues and Legal Precedents in Civil and Commercial Law,

Beijing, People’s Court Press, 1996.

[5] Sun Xianzhong, Overview of China’s Property Law, Beijing: Law Press, 2003, pp.56, pp.73.

[6] Han Song, The Essence of the Farmers' Collective Ownership in China, Science of Law, J .1 (1992).

[7] Selections of Marx and Engels(Vol. III), People’s Publishing House, 1972, pp.12. 
[8] Wang Weiguo, Study on China's Land Rights, Beijing, China University of Political Science and Law Press, 2002.

[9] Tong Rou (Chief Editor), China’s Civil Law, Beijing, Law Press, 1990.

[10] Wang Bufeng: Legal Analysis of China’s Collective Land Ownership [master degree paper], Beijing, China University of Political Science and Law, 2005, pp.25-26.

[11] Chen Xiaojun: Research on Rural Land Legal Regime, Beijing, China University of Political Science and Law Press, 2004. 